\title{
Anatomy of the atmospheric emissions from the transport sector in Greece: trends and challenges
}

\author{
Anastasia K. Paschalidou ${ }^{1} \cdot$ Ilias Petrou $^{2} \cdot$ Georgios Fytianos $^{3}\left[\right.$ - Pavlos Kassomenos $^{2}$
}

Received: 9 July 2021 / Accepted: 8 December 2021 / Published online: 18 January 2022

(c) The Author(s), under exclusive licence to Springer-Verlag GmbH Germany, part of Springer Nature 2021

\begin{abstract}
Emissions of atmospheric pollutants are well-known for their adverse effects on air quality and public health. Additionally, GHG emissions are responsible for the so called "Radiating Forcing" leading to climate change and degradation of ecosystem services. In this work, we analyze the annual emission trends of various air pollutants, including GHGs, from all 4 sectors of transport (roads, aviation, navigation, and railway) in Greece during the 28-year period between 1990 and 2017, in order to examine the confounding dynamics among external forces, such as the major fiscal recession of 2008, and the GHG/pollutant emissions in the country. The analysis is performed with a suite of statistical tools consisting of bivariate correlation analysis, Mann-Kendall test, Sen's slope estimation, and Joinpoint regression analysis, in order to thoroughly study the trends of emissions. It is found that all transport sectors (except for the railway) show a significant increase in their emissions, despite the fiscal recession of 2008 that temporarily decelerated all aspects of economic activity in the country. Given the major share of transport in GHG emissions $(37 \%)$ and air pollution in urban centers, it is essential that the road sector adapts to the new challenges, by means of switching to low-emission technologies and electromobilization. The same applies for the navigation and aviation sectors, which are known pillars of the tourist industry in the country.
\end{abstract}

Keywords Emissions · Greenhouse gases $\cdot$ Climate change $\cdot$ Joinpoint analysis

$\begin{array}{ll}\text { Abbreviations } \\ \text { AAPC } & \text { Average annual percent change } \\ \mathrm{BC} & \text { Black carbon } \\ \mathrm{CH}_{4} & \text { Methane } \\ \mathrm{CO} & \text { Carbon monoxide } \\ \mathrm{CO}_{2} & \text { Carbon dioxide } \\ \mathrm{CO}_{2} \text { eq } & \text { Carbon dioxide equivalent } \\ \mathrm{COPERT} & \text { Computer programme to calculate emissions } \\ & \text { from road transport } \\ \mathrm{EC} & \text { European Commission } \\ \mathrm{EEA} & \text { European Environment Agency }\end{array}$

Responsible Editor: Gerhard Lammel

Georgios Fytianos

gfytia@afs.edu.gr

1 Department of Forestry and Management of the Environment and Natural Resources, Democritus University of Thrace, 68200 Orestiada, Greece

2 Department of Physics, University of Ioannina, 45110 Ioannina, Greece

3 Department of Environmental Science, Perrotis College, American Farm School, Thessaloniki, Greece
EMEP European Monitoring and Evaluation Programme

EU European Union

GHGs Greenhouse gases

HDV Heavy duty vehicle

IPCC Intergovernmental panel on climate change

LDV Light duty vehicle

$\mathrm{N}_{2} \mathrm{O} \quad$ Nitrous oxide

NMHCs Non-methane hydrocarbons

NMVOCs Non-methane volatile organic compound

NOx Nitrogen oxides

PCA Principal component analysis

PM Particulate matter

$\mathrm{SO}_{2} \quad$ Sulfur dioxide

SOx $\quad$ Sulfur oxides

TSP Total suspended particles

VOCs Volatile organic compounds 


\section{Introduction}

It is well-known that ambient air pollution is responsible for many harmful effects. Among them are the adverse effects on human health and wellbeing, and climate change. Specifically, air pollution is one of the greatest factors of environmental degradation, and was responsible for 6.5 million of premature deaths worldwide in 2015 (Landrigan et al. 2017). Typical adverse health effects of air pollution include cardiovascular and respiratory mortality and morbidity (see, e.g., Hoek et al. 2001; Pope and Dockery, 2006). On the other hand, certain atmospheric pollutants are responsible for the so-called "Radiative Forcing," resulting in climate change in the form of global warming (IPCC 2013). Existing evidence indicates that increased temperatures, in combination with other climate extremes, have already resulted in tropicalization and desertification in various parts of the planet (Patz et al 2005; Salvati, 2014; Huang et al. 2016). The temperature rise is projected to continue, and is estimated to reach 1.4-5.8 ${ }^{\circ} \mathrm{C}$ by 2100 (Kjellström et al. 2011), posing an additional burden on the environment and human health (Stott et al. 2004; Linares et al. 2020).

Power plants, road traffic, industry, and agriculture are the main anthropogenic sectors that emit atmospheric pollutants (Bignal et al., 2007). Additionally, the combustion of fossil fuels (such as wood, coal, oil etc.) for domestic heating represents another important source of air pollution (especially particulate matter) in wintertime (Reisen et al., 2019; Adesina et al., 2020). Typical air pollutants detected in the close vicinity of anthropogenic sources are nitrogen oxides, carbon monoxide, particulate matter and benzene.

In order to reduce the aforementioned emissions and protect public health and the environment, the EC has introduced a number of directives that the member-states need to include in their national air pollution policies. Additionally, the EU joined the 2015 Paris Agreement and pledged to reduce its GHG emissions by $40 \%$ before 2030 , starting as of January $1^{\text {st }} 2020$.

Although the potential of reducing emissions from power plants, industry and agriculture is high and could be materialized with the application of long-term policies, reducing transport emissions is a rather challenging endeavour. According to the Paris agreement, road transport is one of the main sectors where $\mathrm{CO}_{2}$ emissions need to be reduced (regulation 2019/631). In 2020, Regulation (EU) 2019/631, which replaced the former Regulations (EC) 443/2009 (cars) and (EU) 510/2011 (vans), entered into force, setting new $\mathrm{CO}_{2}$ emission performance standards for new passenger cars and vans. From its application, the average $\mathrm{CO}_{2}$ emissions from new passenger cars registered in Europe have decreased by $12 \%$ compared to 2019 and the share of electric cars has tripled (https:// ec.europa.eu/clima/eu-action/transport-emissions/roadtransport-reducing-co2-emissions-vehicles/co2-emissionperformance-standards-cars-and-vans_en). The new EC target is achieving climate neutrality in the EU by 2050 , including the intermediate target of an at least $55 \%$ net reduction in GHG emissions by 2030 .

GHG emissions from ships and airplanes are also of importance, in light of the continuous global increase in the number of domestic and international (including charter) flights and sea cruises (added to traditional commercial navigation). During the touristic periods of the year, emissions from ships, cars and airplanes peak. This is more evident in popular touristic destinations, such as the Mediterranean area. Since 2012, for the aviation-related $\mathrm{CO}_{2}$ emissions, EU established the EU emissions trading system (EU ETS). Under the EU ETS, all airlines operating in Europe are required to monitor, report and verify their emissions, and to surrender allowances against those emissions. They receive tradeable allowances covering a certain level of emissions from their flights per year. The system has so far contributed to reducing the carbon footprint of the aviation sector by more than 17 million tonnes per year, with the compliance covering over $99.5 \%$ of the emissions (https://ec.europa.eu/ clima/eu-action/transport-emissions/reducing-emissionsaviation_en).

In 2013, the EC set out a strategy towards monitoring and reducing the GHG emissions from the shipping industry. The recent amendment to the EU Emissions Trading System (ETS) Directive, by Directive (EU) 2018/410 of the European Parliament and the Council, emphasizes the need to act on shipping emissions in addition to all other sectors of the economy (https://ec.europa.eu/clima/ eu-action/transport-emissions/reducing-emissions-shipp ing-sector_en).

The aforementioned concerns on the impact of the various transport sectors on GHG emissions have recently been the subject of significant research interest. For instance, Murena et al. (2018) studied the impact of cruise ship emissions on the air quality of Naples, Italy, while Lo et al. (2020) analysed the determinants of $\mathrm{CO}_{2}$ emissions originating from passenger traffic in Lombardy, Italy. Iarocci et al. (2019) studied the emissions from road transport in Italy and found a considerable decrease, complying with the EU policies, while Bebkiewicz et al. (2020) found an increase of $\mathrm{CO}_{2}$ and $\mathrm{N}_{2} \mathrm{O}$ emissions and a decrease of $\mathrm{CH}_{4}$ emissions in Poland due to the dynamic development of motorization in recent years. Along the same lines, Sobrino and Monzon (2018) proposed a methodology to achieve a sustainable transport system in Spain, by means of reducing the road transport emissions.

In Greece, the transport sector is one of the most challenging GHGs sources (Koroneos and Nanaki, 2007), 
mainly due to the rapid touristic development reported after the economic recession of 2008. During the last decade, all transport branches (except for the railway) have increased their share in the total $\mathrm{CO}_{2}$-eq emission budget. Currently, the road transport contributes up to $22 \%$ of the total GHGs emissions in Greece (http://unfecc.int), while an additional $13 \%$ originates from the international navigation/aviation sector. The objective of this study is to analyze the trends in atmospheric emissions within the four transport sectors (road, navigation, aviation, railway) in Greece between 1990-2017, using a variety of statistical techniques, in order to examine the confounding dynamics among external forces, such as the major fiscal recession of 2008, and the GHG/pollutant emissions in the country. This analysis could shed light in understanding the emissions' mosaic under unforeseen phenomena and could highlight the interrelation among the various aspects of social/economic life and the attempt of Greece to comply with the EU mitigation policies. The latter seems of particular importance in light of the current COVID-19 pandemic, when changes in social/economic activities have resulted in significant shifts in GHG/pollutant emissions worldwide.

\section{Materials and methods}

In this study, the emissions related to the four transport sectors (e.g., road transport, aviation, navigation, railway) were considered. In particular, yearly values (in kilotons) of the three main GHGs (namely $\mathrm{CO}_{2}, \mathrm{CH}_{4}$ and $\mathrm{N}_{2} \mathrm{O}$ ), as well as the emissions of $\mathrm{CO}, \mathrm{NH}_{3}, \mathrm{NMVOCs}$, NOx in the form of $\mathrm{NO}_{2}$, $\mathrm{SOx}$ in the form of $\mathrm{SO}_{2}, \mathrm{PM}_{10}, \mathrm{PM}_{2.5}$, Black Carbon and TSP were studied. The data were collected by the Greek Ministry of Environment, EEA/EMEP and the United Nations Framework Convention on Climate Change (UNFCCC) (http://unfccc.int). It is noted that hydrofluorocarbons (HFCs), perfluorocarbons (PFCs) and hexafluoride (SF6) emissions were not considered, as these are mainly related to industrial activities. In order to estimate the GHGs emitted from the road transport sector, a standardized methodology consistent with the 2006 IPCC Guidelines for national Greenhouse Gas Inventories (IPCC, 2006) and the 2019 EEA/EMEP Emission Inventory Guidebook, as well as the COPERT 5 software were used. COPERT is a European application to calculate the emissions from road transport, including appropriate methodology to estimate the local vehicle fleet emissions. Different methods and calculation processes are used to estimate the exhaust and nonexhaust emissions of the various pollutants (Ntziachristos et al. 2009). Specifically, exhausted pollutants $\left(\mathrm{E}_{\mathrm{EXH}}\right)$ emitted by the vehicle engine are calculated with the following equation:
$\mathrm{E}_{\mathrm{EXH}}=\mathrm{E}_{\mathrm{HOT}}+\mathrm{E}_{\mathrm{COLD}}$

where $\mathrm{E}_{\mathrm{HOT}}$ are emissions (g) during stabilised (hot) engine operation and $\mathrm{E}_{\mathrm{COLD}}$ are emissions ( $\mathrm{g}$ ) during transient thermal engine operation (cold start). For a given timeperiod and activity level, hot emissions are calculated by:

$\mathrm{E}_{\mathrm{HOT}}=\mathrm{N} \times \mathrm{M} \times \mathrm{e}_{\mathrm{HOT}}$

where $\mathrm{N}$ is the number of vehicles [veh], $\mathrm{M}$ is the mileage per vehicle $[\mathrm{km} / \mathrm{veh}]$ and $\mathrm{e}_{\mathrm{HOT}}$ is an emission factor $[\mathrm{g} / \mathrm{km}]$ for a specific pollutant. The cold-start emissions $\left(\mathrm{E}_{\mathrm{COLD}}\right)$ occur for all vehicle categories, before the vehicles reach their normal operation temperature and they seem to be most likely for urban and rural driving, where the number of starts is more frequent. Equation (3) is used to calculate cold-start emissions:

$\mathrm{E}_{\mathrm{COLD}}=\beta \times \mathrm{N} \times \mathrm{M} \times \mathrm{e}_{\mathrm{HOT}} \times\left(\mathrm{e}^{\mathrm{COLD}} / \mathrm{e}^{\mathrm{HOT}}-1\right)$

where $\beta$ is the fraction of mileage driven with a cold engine before the engine reaches its normal operation temperature. It depends on the pattern of vehicle used and the ambient temperature, while the term $\left(\mathrm{e}^{\mathrm{COLD}} / \mathrm{e}^{\mathrm{HOT}}-1\right)$ refers to the emission level compared to hot emissions.

The road transport emissions presented here are the summation of emissions from passenger cars, light and heavyduty vehicles, buses, mopeds and motorcycles. The emissions related to road abrasion and tire and brake wear were not considered. The navigation emissions include emissions from both domestic and international shipping and cruises in the Greek seas. Similarly, the aviation emissions include domestic and international flights, as well as charter flights.

The study of emission trends was contacted using a suite of different statistical techniques. This suite consists of the following techniques:

- A bivariate analysis among variables was performed, using the Pearson correlation coefficient. The Pearson correlation is widely used to measure the statistical relationship, or association, between two continuous variables (where value $r=1$ means a perfect positive correlation and value $r=-1$ means a perfect negative correlation).

- A Principal Component Analysis (PCA) was applied with the IBM-SPSS 26.0 statistical software, to identify homogeneous trends. PCA is widely used to reduce a dataset which contains a big number of variables to a dataset with fewer new variables that are uncorrelated and represent a parge fraction of the variability included in the original set.

- The Mann-Kendall's correlation coefficient (i.e. the rankbased nonparametric test for assessing the significance of a trend) was estimated with the IBM-SPSS 26.0 statisti- 
Fig. 1 Annual variation of $\mathrm{CO}_{2}$-eq emissions from roads, navigation and aviation in Greece between 1990 and 2017

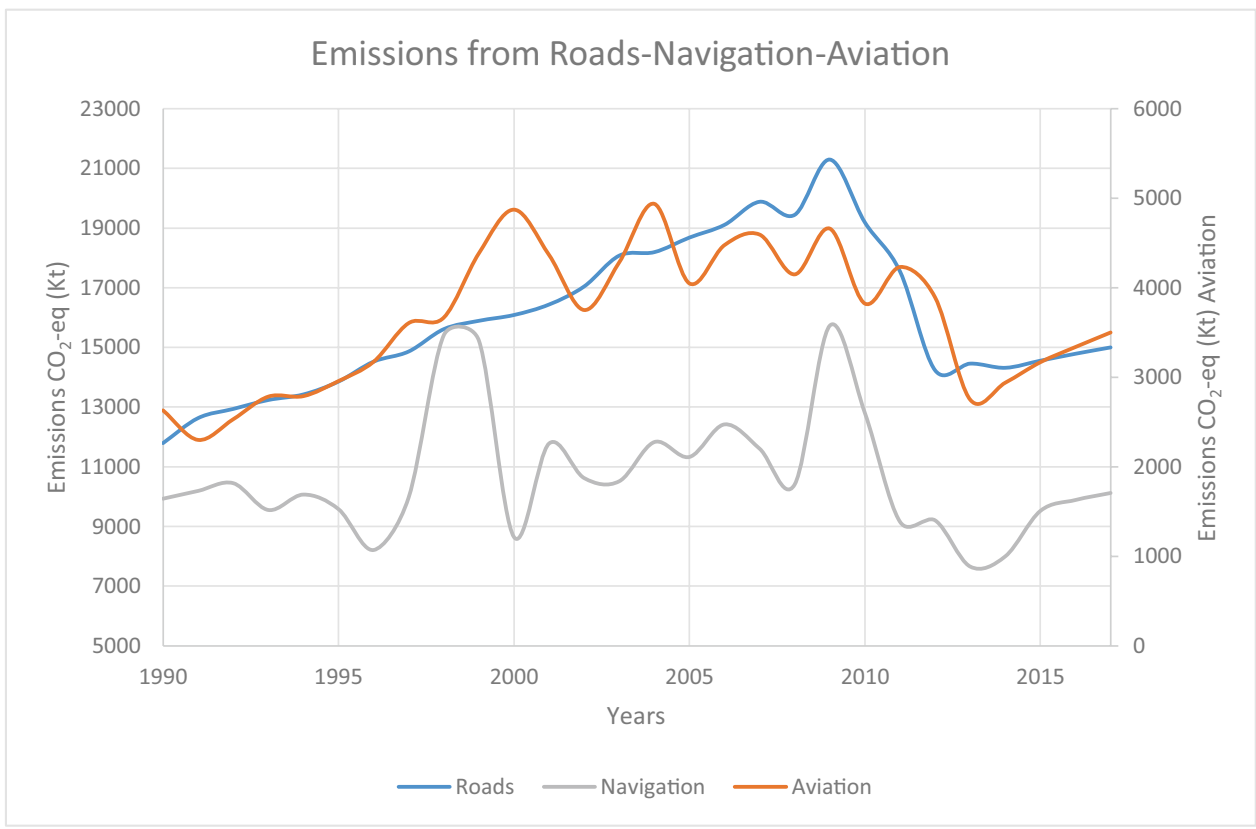

cal software, to investigate whether variables could be regarded as statistically dependent (Kendall and Gibbons, 1990).

- Additionally, the Sen's slope estimation was performed with the MAKESENS 1.0 statistical software (Sirois, 1998), in order to examine whether the pollutants studied present a statistically significant monotonic increase/ decrease. In general, the Sen's slope is used to estimate the trend of a dataset and is commonly used in combination with the Mann-Kendall test to provide both an estimate and a test for the trend.

- Finally, a Joinpoint regression analysis was performed with the "Joinpoint regression" software (version 4.8.0.0), in order to examine the time-trends of the emissions. The advantage of this analysis is that it identifies turning points (i.e., significant changes) in trends and allows for the Average Annual Percent Change (AAPC) to be estimated (Kim et al. 2000). It is noted that the significance level for this analysis was set at $p<0.05$.

\section{Results and discussion}

The road transport $\mathrm{CO}_{2}$-eq emissions in Greece accounted for $22.6 \%$ of the total emissions in 2017, while an additional $13.2 \%$ originated from the international aviation and navigation sectors. Figure 1 depicts the annual variation of emissions from roads, navigation, and aviation, separately.

The contribution of each transport sector in the total $\mathrm{CO}_{2}$-eq transport emissions for 2017 is shown in Fig. 2. Road transport presents $51.8 \%$ of the total $\mathrm{CO}_{2}$-eq transport emissions, while navigation contributes up to $36.1 \%$.

\section{Contribution of the transport sectors}

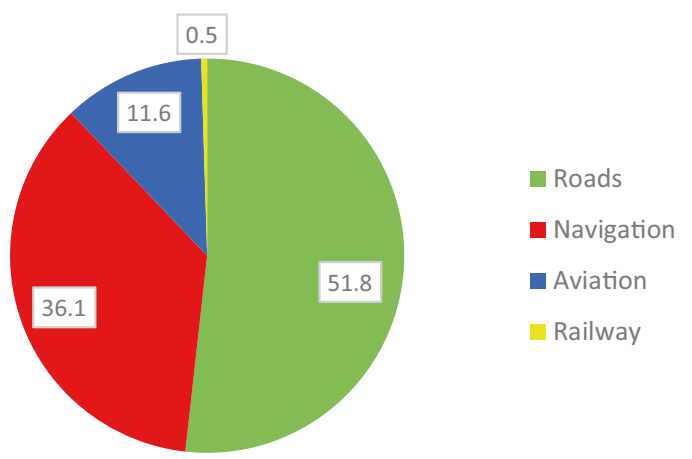

Fig. 2 Percentage of $\mathrm{CO}_{2}$-eq emissions per transport sector during 2017

Aviation has a smaller contribution (11.6\%), while railway accounts for $0.5 \%$.

The road sector $\mathrm{CO}_{2}$-eq emissions increased from 12,000 to almost $15,000 \mathrm{Kt}$ between 1990-2017, presenting an increase of almost $25 \%$. It is noteworthy that the road sector emissions continued to increase until 2008-2009 (with a peak at 21,295 Kt), at which point they decreased sharply, due to the economic recession that decelerated almost all aspects of financial activity in the country (Sadorsky, 2020; Roinioti and Koroneos, 2017). This pattern was confirmed for the emissions of each specific vehicle category (passenger cars, light-duty vehicles (LDV), heavy-duty vehicles and buses (HDV), mopeds and motorcycles) (Fig. 3). In the case 
Fig. 3 Annual variation of $\mathrm{CO}_{2}$-eq emissions from roads per vehicle category between 1990 and 2017

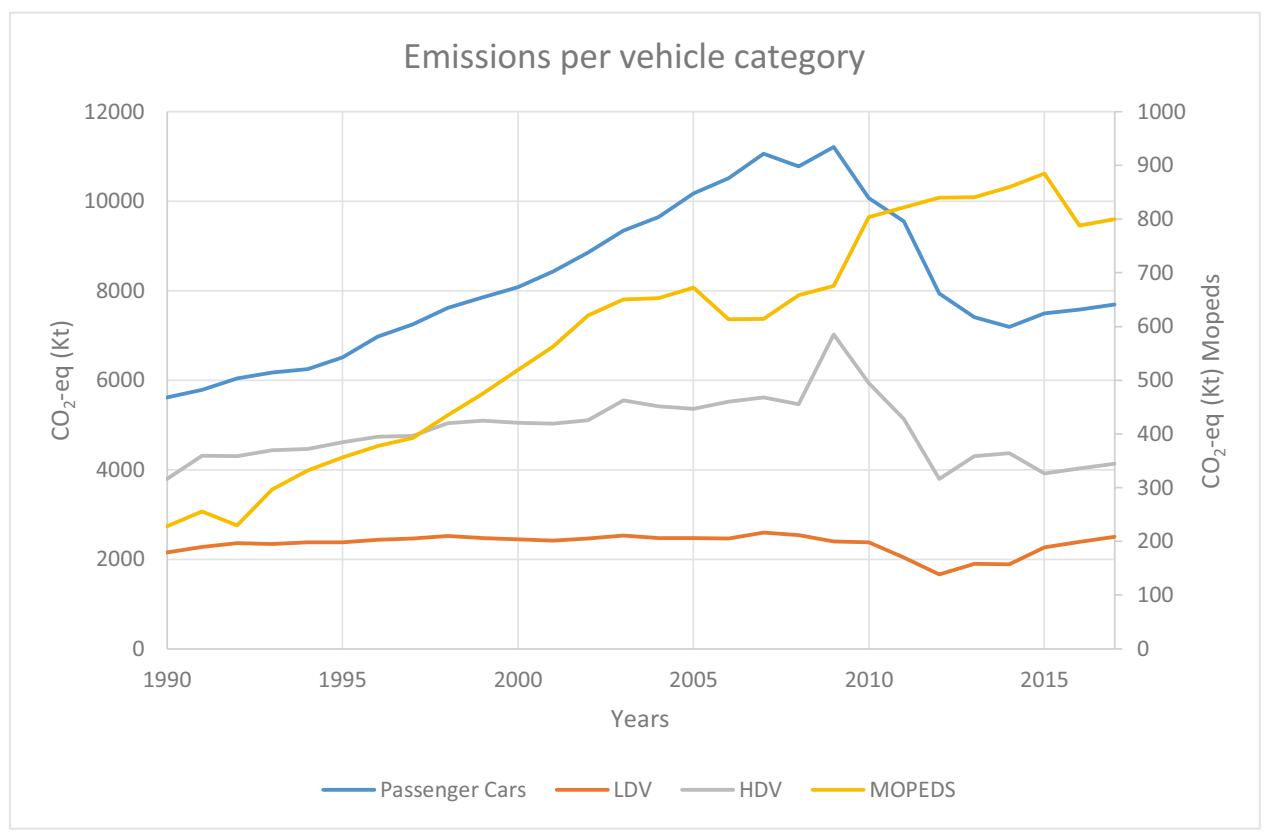

Table 1 Mann-Kendall test and Sen's slope estimation results for the road sector emission trends

\begin{tabular}{llccl}
\hline Pollutant & $\begin{array}{l}\text { Mann-Kend- } \\
\text { all Tau-Z }\end{array}$ & $P$-value & Sen's Slope & Trend \\
\hline $\mathrm{CO}_{2}$ & 3.50 & 0.001 & 333.107 & Increase \\
$\mathrm{CH}_{4}$ & -1.96 & 0.1 & -0.043 & Stable \\
$\mathrm{N}_{2} \mathrm{O}$ & -1.04 & $>0.1$ & -0.006 & Stable \\
$\mathrm{CO}$ & -7.13 & 0.001 & -26.205 & Decrease \\
$\mathrm{NH}_{3}$ & 2.79 & 0.01 & 0.050 & Increase \\
$\mathrm{NMVOC}$ & -7.05 & 0.001 & -5.309 & Decrease \\
$\mathrm{NOx}$ & -3.63 & 0.001 & -1.888 & Decrease \\
$\mathrm{SOx}$ & -5.53 & 0.001 & -0.770 & Decrease \\
$\mathrm{PM}_{10}$ & -3.34 & 0.001 & -0.069 & Decrease \\
$\mathrm{PM}_{2.5}$ & -4.02 & 0.001 & -0.085 & Decrease \\
$\mathrm{BC}$ & -2.84 & 0.01 & -0.032 & Decrease \\
$\mathrm{TSP}$ & -1.38 & 0.001 & -0.044 & Stable \\
\hline
\end{tabular}

of mopeds and motorcycles specifically, the $\mathrm{CO}_{2}$-eq emissions almost quadrupled during the studied period. For the rest of transport sectors, navigation and aviation presented a similar behavior with increase of their $\mathrm{CO}_{2}$-eq emissions (Fig. 1). The Railway has been the only exception in the aforementioned pattern, and presented a significant decrease (37\%) throughout the 28-years period (not shown in Fig. 1).

In Table 1, the results of the Mann-Kendall test for the road sector are shown. According to the table, a monotonic increase for $\mathrm{CO}_{2}$ and $\mathrm{NH}_{3}$ was detected, whereas for $\mathrm{CH}_{4}$, $\mathrm{N}_{2} \mathrm{O}$ and TSP, a stabilization pattern was found. These findings contradict the general trend for decrease detected in the EU28 (-21.7\%) during the period of 1990-2015, which was mainly related to the reduction of fossil fuel $\mathrm{CO}_{2}$ emissions (Crippa et al. 2019). However, differences are not rare within the $\mathrm{EU}$ area. For instance, $\mathrm{CH}_{4}$ emissions from landfills are still increasing in some Southern European countries, such as Cyprus and Spain (Crippa et al. 2019; Olivier et al 2017). Poland presents a general increasing trend in GHGs emission from the road sector due to the dynamic development of motorization (Bebkiewicz et al 2020), while Italy presents a stabilization pattern (Iarocci et al. 2019). On a global scale, China and India increased their emissions by about $660 \%$ and 335\% respectively during 1990-2015, while Japan's emissions practically remained stable and Russia showed a reduction of $27 \%$ due to the collapse of the eastern European social economic system during this period (Ritchie and

Table 2 Mann-Kendall test and Sen's slope estimation results for the navigation sector emission trends

\begin{tabular}{llcll}
\hline Pollutant & $\begin{array}{l}\text { Mann-Kend- } \\
\text { all Tau-Z }\end{array}$ & $P$-value & Sen's Slope & Trend \\
\hline $\mathrm{CO}_{2}$ & -0.30 & $>0.1$ & -11.990 & Stable \\
$\mathrm{CH}_{4}$ & 0.77 & $>0.1$ & 0.002 & Stable \\
$\mathrm{N}_{2} \mathrm{O}$ & -3.26 & 0.01 & -0.027 & Decrease \\
$\mathrm{CO}$ & -2.86 & 0.01 & -0.342 & Decrease \\
$\mathrm{NMVOC}$ & -2.90 & 0.01 & -0.130 & Decrease \\
$\mathrm{NOx}$ & -2.86 & 0.01 & -3.854 & Decrease \\
$\mathrm{SOx}$ & -2.02 & 0.05 & -0.023 & Decrease \\
$\mathrm{PM}_{10}$ & -1.52 & $>0.1$ & -0.151 & Stable \\
$\mathrm{PM}_{2.5}$ & -1.52 & $>0.1$ & -0.139 & Stable \\
$\mathrm{BC}$ & -2.43 & 0.05 & -0.049 & Decrease \\
$\mathrm{TSP}$ & -1.52 & $>0.1$ & -0.155 & Stable \\
\hline
\end{tabular}




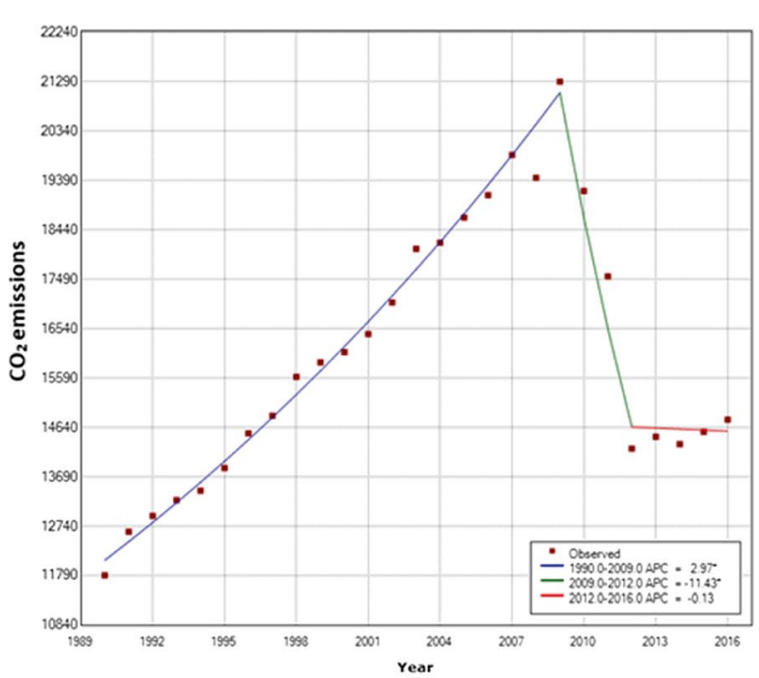

(a)

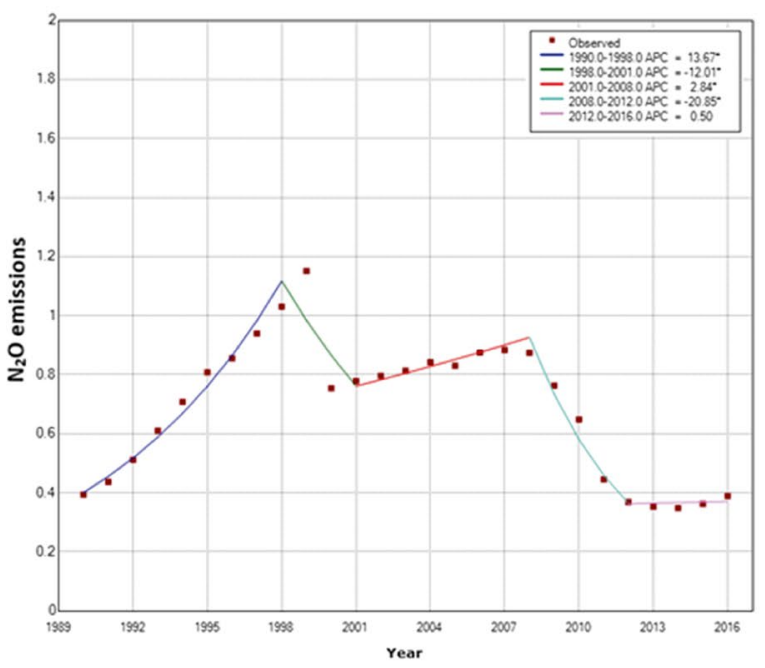

(c)

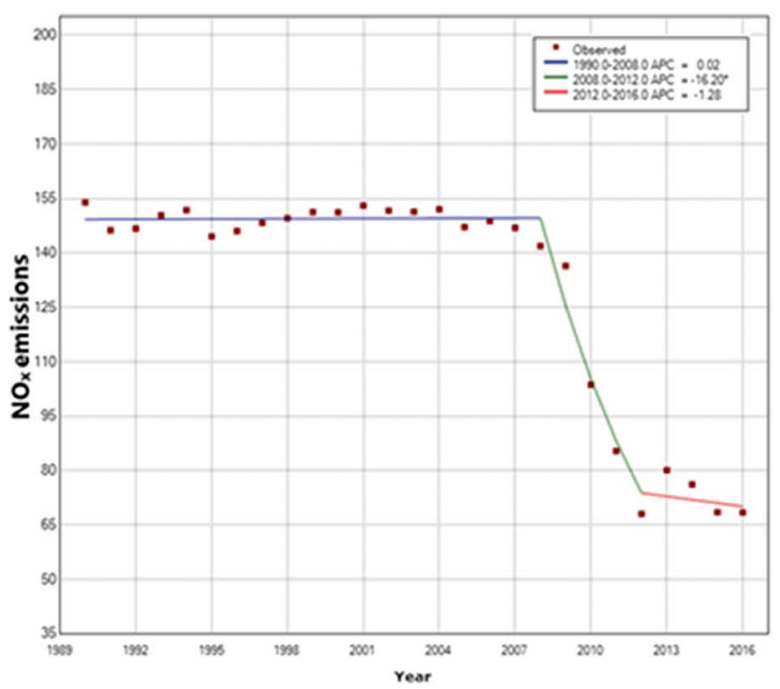

(e)

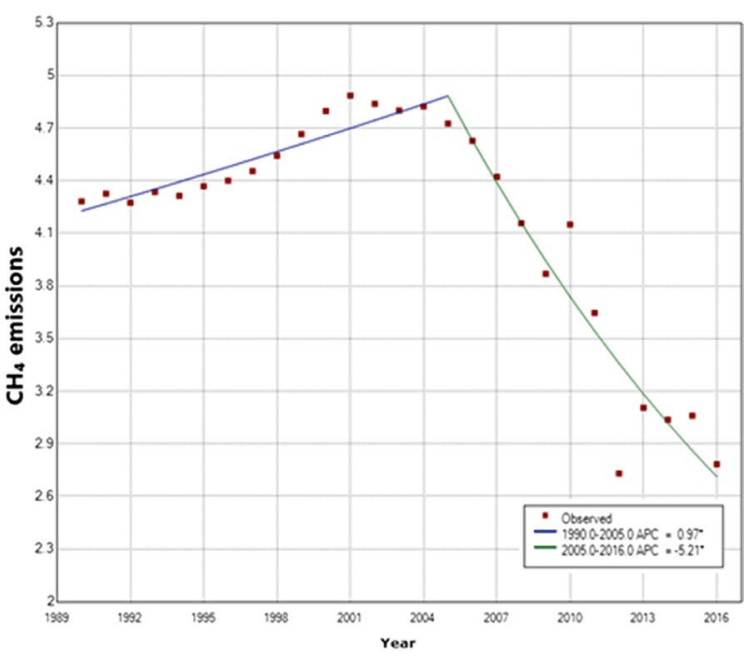

(b)

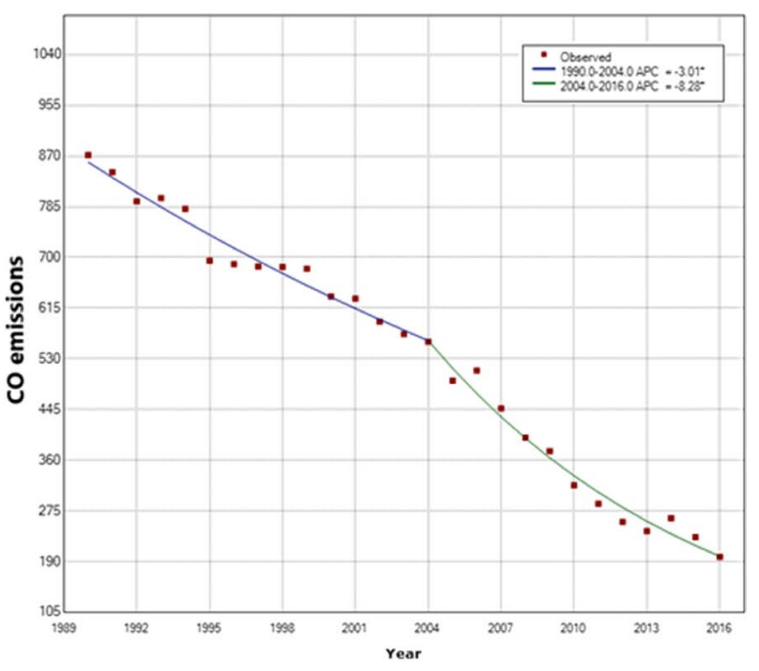

(d)

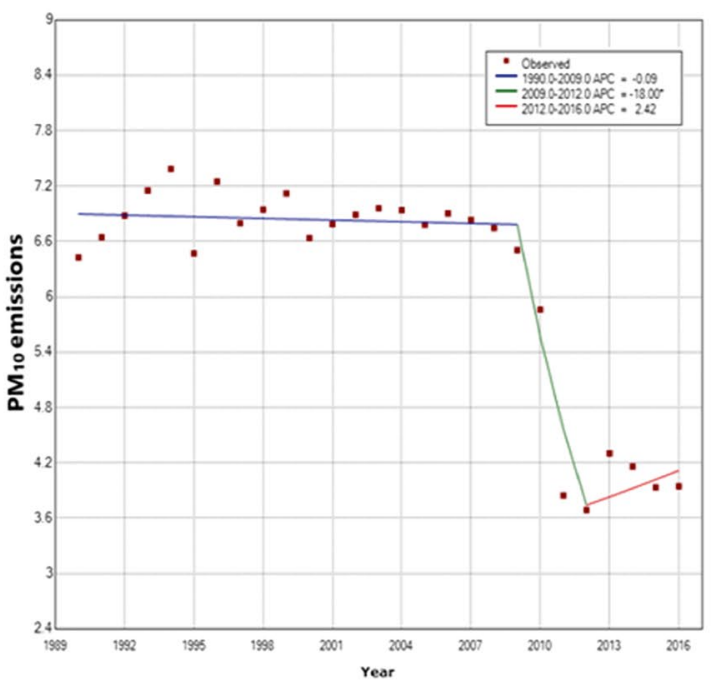

(f) 
4Fig. 4 Joinpoint regression for the road sector emissions of $\mathrm{CO}_{2}$ (a), $\mathrm{CH}_{4}(\mathrm{~b}), \mathrm{N}_{2} \mathrm{O}$ (c), $\mathrm{CO}(\mathrm{d}), \mathrm{NOx}(\mathrm{e})$ and $\mathrm{PM}_{10}$ (f)

Roser, 2018; Olivier et al. 2017). Emissions in the USA also increased, but showed a reduction during the last years of the period (Ritchie and Roser, 2018).

For the rest of pollutants, namely CO, NMVOC, NOx, SOx, $\mathrm{PM}_{10}, \mathrm{PM}_{2.5}$ and $\mathrm{BC}$, a statistically significant decrease was found (Table 1). This decrease reflects the restrictive measures adopted in the EU, and is consistent among many EU member-states. Carslaw et al. (2016) showed that NOx concentrations have decreased in London since around 2010. This decrease was driven by the relatively large reductions in the amount of $\mathrm{NO}_{2}$ directly emitted by vehicles, from around $25 \mathrm{vol} \%$ in 2010 to $15 \mathrm{vol} \%$ in 2014 in inner London. Cattani et al. (2010) found a decreasing trend for all of the aforementioned pollutants in Rome during 1999-2008. Similar trends were found in German cities. Specifically, Matthias et al (2020) developed a novel model to calculate current day traffic emissions in Germany, and found that by 2040, NOx emissions from traffic will decrease by approximately $80 \%$, while PM emissions will present a smaller reduction (13\%). On the whole, Uherek et al. (2010) found that vehicle exhaust emission control has successfully reduced emissions of NOx, CO, VOCs and PM in industrialised countries, although in developing countries pollutant emissions have been showing significant growth, adversely affecting many populations.

A small degree of diversification was observed among the different branches of the road sector. Specifically, for $\mathrm{CH}_{4}$ a statistically significant decrease was found for passenger cars and light-duty vehicles (Tables S1 and S2, provided as supplementary material), while for the rest of the categories a statistically significant increase was detected (Tables S3 and S4). For $\mathrm{CO}_{2}$, the trend was not statistically significant for light-duty vehicles (Table S2). On the other hand, an increase in $\mathrm{N}_{2} \mathrm{O}$ emissions was detected for the mopeds and motorcycles class (Table S4). These diversifications most likely reflect the varying age of the engines and the driving conditions (Giechaskiel, 2020; Vasic and Weilenmann, 2006).

Regarding the railway sector, a statistically significant decrease for all pollutants was found (Table S5), probably reflecting the replacement of the old fleet with new, lower emission trains (Heinold and Meisel, 2018; de Miranda Pinto et al., 2018). For the navigation sector, no statistically significant increase/decrease for the two main greenhouse gases $\left(\mathrm{CO}_{2}\right.$ and $\left.\mathrm{CH}_{4}\right)$, particulates $\left(\mathrm{PM}_{10} \mathrm{PM}_{2.5}\right)$ and TSP was observed, while for the rest of the pollutants (including $\mathrm{N}_{2} \mathrm{O}$ ) a statistically significant decrease was detected (Table 2), probably reflecting the partial renewal of the fleet.

Finally, for the aviation sector, a statistically significant increase was registered for NMVOCs, NOx, SOx, particulates and $\mathrm{BC}$. For all three GHGs and $\mathrm{CO}$, a stabilization trend was found, though not statistically significant for $\mathrm{CH}_{4}$ and $\mathrm{CO}$ (Table S6).

Joinpoint regression analysis was then applied, in order to further study the emission trends, by means of identifying specific time-points when significant changes in trends were recorded. The results for the road sector are shown in Fig. 4.

For $\mathrm{CO}_{2}$ (Fig. 4a), a steep increase of emissions is observed up to 2009 , followed by a steep decrease up to 2012. Following that, a stabilization of emissions is observed. This is consistent with the characteristics and the evolution of the economic crisis that affected Greece after 2009 (Sadorsky, 2020; Valavanidis et al. 2015). The impact of the fiscal recession is evident on all emissions, although various differences are observed among different pollutants. Interestingly, $\mathrm{CO}$ emissions show a continuous decrease throughout the years, probably reflecting improvements in the technology of vehicles' engines.

For the aviation sector (Fig. 5), all three GHGs $\left(\mathrm{CO}_{2}, \mathrm{CH}_{4}\right.$ and $\mathrm{N}_{2} \mathrm{O}$ ) present a similar pattern, marked by an increase up to 2004, followed by a decrease (figures for $\mathrm{CH}_{4}$ and $\mathrm{N}_{2} \mathrm{O}$ are omitted). For CO (Fig. 5b) and NMVOCs (figure not shown), the impact of the economic recession is evident.

For the navigation sector, an almost stable behavior was found for $\mathrm{CO}_{2}$ and $\mathrm{CH}_{4}$ (figures not shown). For $\mathrm{N}_{2} \mathrm{O}$ (Fig. 6a), a decrease was detected between 2009-2013, followed by an increase. This increase probably reflects the economic recovery and the development of the touristic ship-cruises industry in Greece.

Similarly, for the railway sector's $\mathrm{CO}_{2}$ emissions (Fig. 6b), the steep decrease between the years 2008-2012 is evident. This pattern is common for all railway emissions (figures not shown).

Table 3 presents the Pearson correlation coefficients among pollutants of the road sector. The coefficients are mainly positive, indicating a simultaneous change for most sets of pollutants. For example, NOx correlated significantly (positively) with $\mathrm{PM}_{10}$ (0.973), $\mathrm{PM}_{2.5}$ (0.986), BC (0.978), and TSP $(0,954)$ probably suggesting photochemical formation driven by the presence of nitrogen oxides (NuñezAlonso et al. 2019; Cattani et al., 2010). On the other hand, the anticorrelation observed for the pair NMVOC- $\mathrm{CO}_{2}$, probably reflects ozone formation in the troposphere (Matthes et al. 2007). The anticorrelation observed for the pair $\mathrm{SOx}-\mathrm{CO}_{2}$ may be related to the vehicle and industrial production technology (Huang et al. 2018). Regarding the pair of $\mathrm{CO}-\mathrm{CO}_{2}$, the anticorrelation observed does not come as a surprise, as $\mathrm{CO}$ is a product of inefficient combustion that has often been used as a tracer of $\mathrm{CO}_{2}$ from combustion (Turnbull et al. 2006). The emission ratio of $\mathrm{CO}_{2}$ to $\mathrm{CO}$ varies with the efficiency of combustion (Andreae and Merlet, 2001), depending on the emission control technologies adopted, as well as vehicle maintenance 


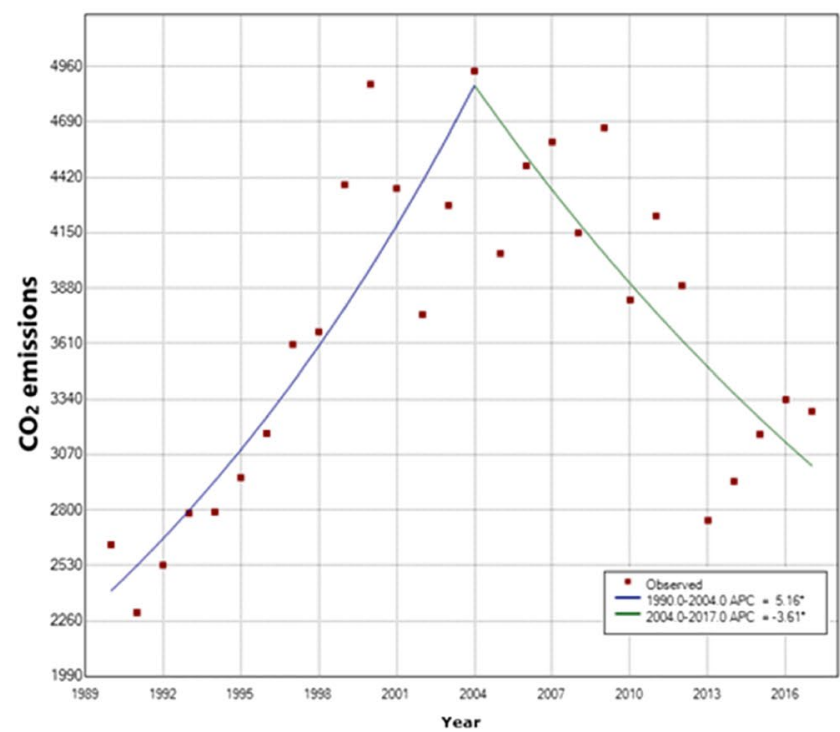

(a)

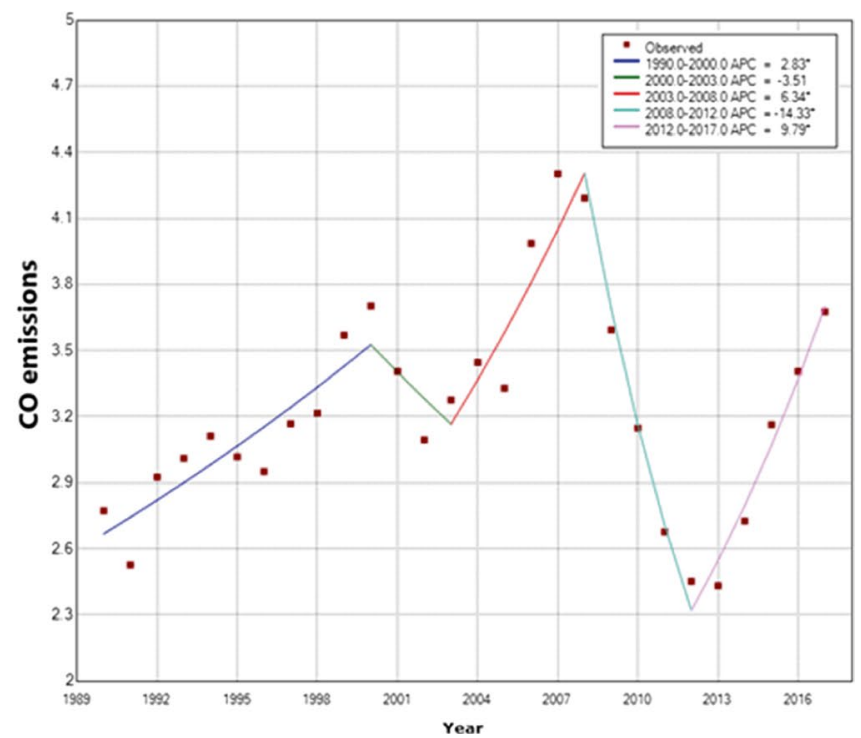

(b)

Fig. 5 Joinpoint regression for the aviation sector emissions of $\mathrm{CO}_{2}$ (a) and $\mathrm{CO}$ (b)

(Bishop and Stedman, 2008). Finally, the anticorrelation observed between $\mathrm{NH}_{3}$ and all other pollutants probably reflects cold start conditions, and is in agreement with the mechanisms described in recent works (Behera et al. 2013; Lehtipalo et al. 2018; Lachatre et al. 2019; Viatte et al. 2020).

In Tables S7-S10, the Pearson correlation coefficients are shown, separately, for the four branches of the road sector.
Although the aforementioned pattern is generally repeated, various differences (especially for light and heavy-duty vehicles) reflect the different fuel used and the driving conditions.

*Correlation significant at the 0.05 level.

**Correlation significant at the 0.01 level.

For the railway (tables not shown), navigation (Table 4) and aviation sector (Table S11) all Pearson correlation

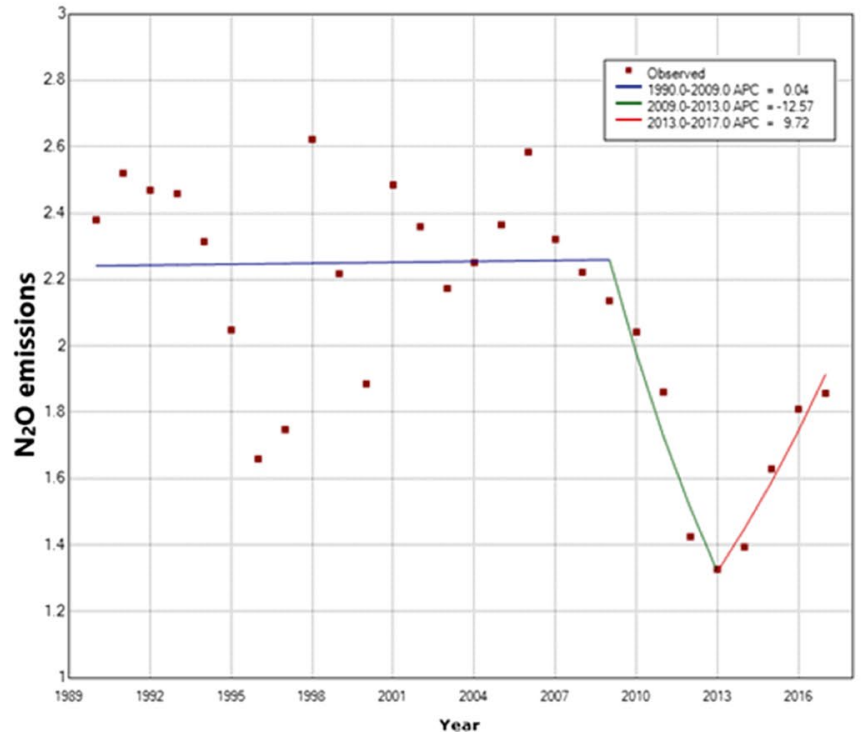

(a)

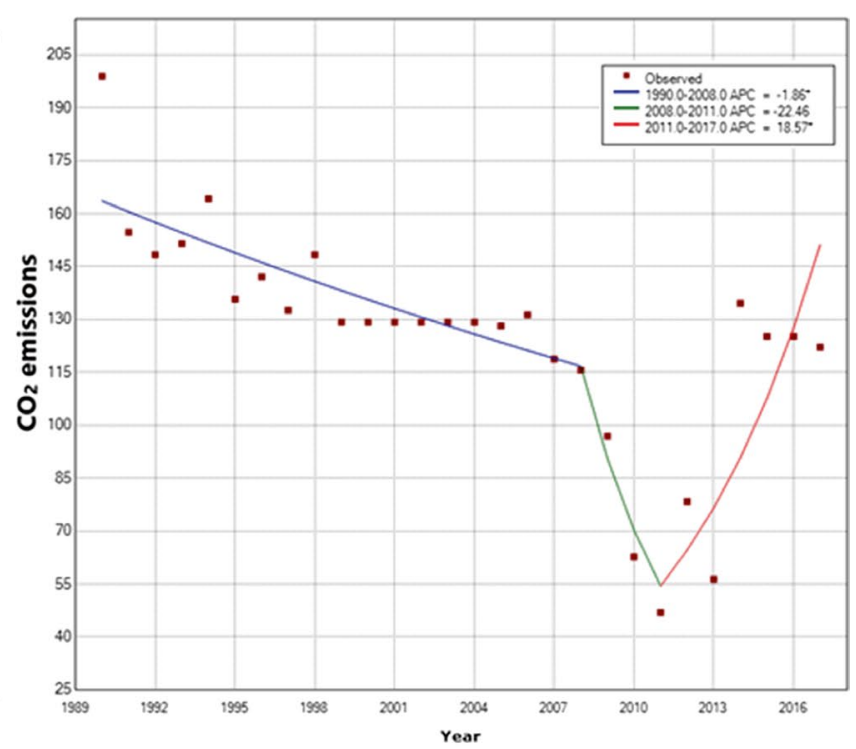

(b)

Fig. 6 Joinpoint regression for the navigation sector emissions of $\mathrm{N}_{2} \mathrm{O}$ (a) and the railway sector emissions of $\mathrm{CO}_{2}$ (b) 
Table 3 Pearson correlation coefficients for the road transport sector

\begin{tabular}{|c|c|c|c|c|c|c|c|c|c|c|c|c|}
\hline & $\mathrm{CO}_{2}$ & $\mathrm{CH}_{4}$ & $\mathrm{~N}_{2} \mathrm{O}$ & $\mathrm{CO}$ & $\mathrm{NH}_{3}$ & NMVOC & NOx & SOx & $\mathrm{PM}_{10}$ & $\mathrm{PM}_{2.5}$ & BC & TSP \\
\hline $\mathrm{CO}_{2}$ & 1 & & & & & & & & & & & \\
\hline $\mathrm{CH}_{4}$ & 0.255 & 1 & & & & & & & & & & \\
\hline $\mathrm{N}_{2} \mathrm{O}$ & $0.476^{*}$ & $0.759 * *$ & 1 & & & & & & & & & \\
\hline $\mathrm{CO}$ & -0.422 & $0.715^{* *}$ & 0.374 & 1 & & & & & & & & \\
\hline $\mathrm{NH}_{3}$ & $0.705 * *$ & -0.111 & 0.053 & $-0.624 * *$ & 1 & & & & & & & \\
\hline NMVOC & $-0.511 * *$ & $0.644 * *$ & 0.340 & $0.989 * *$ & $-0.686 * *$ & 1 & & & & & & \\
\hline NOx & 0.121 & $0.936 * *$ & $0.720 * *$ & $0.834 * *$ & -0.267 & $0.773 * *$ & 1 & & & & & \\
\hline SOx & $-0.673 * *$ & 0.326 & 0.075 & $0.866 * *$ & $-0.793 * *$ & $0.900 * *$ & $0.514 * *$ & 1 & & & & \\
\hline $\mathrm{PM}_{10}$ & 0.154 & $0.909 * *$ & $0.756^{* *}$ & $0.793 * *$ & -0.303 & $0.740 * *$ & $0.973 * *$ & $0.516 * *$ & 1 & & & \\
\hline $\mathrm{PM}_{2.5}$ & 0.088 & $0.912 * *$ & $0.720 * *$ & $0.842 * *$ & -0.347 & $0.790 * *$ & $0.986 * *$ & $0.573 * *$ & $0.991 * *$ & 1 & & \\
\hline $\mathrm{BC}$ & 0.132 & $0.896 * *$ & $0.727 * *$ & $0.807 * *$ & -0.311 & $0.752 * *$ & $0.978 * *$ & $0.535 * *$ & $0.979 * *$ & $0.988 * *$ & 1 & \\
\hline TSP & 0.338 & $0.934 * *$ & $0.808 * *$ & $0.684 * *$ & -0.156 & $0.614 * *$ & $0.954 * *$ & 0.370 & $0.976 * *$ & $0.959 * *$ & $0.956 * *$ & 1 \\
\hline
\end{tabular}

Table 4 Pearson correlation coefficients for the navigation sector

\begin{tabular}{|c|c|c|c|c|c|c|c|c|c|c|c|}
\hline & $\mathrm{CO}_{2}$ & $\mathrm{CH}_{4}$ & $\mathrm{~N}_{2} \mathrm{O}$ & $\mathrm{CO}$ & NMVOC & NOx & SOx & $\mathrm{PM}_{10}$ & $\mathrm{PM}_{2.5}$ & $\mathrm{BC}$ & TSP \\
\hline $\mathrm{CO}_{2}$ & 1 & & & & & & & & & & \\
\hline $\mathrm{CH}_{4}$ & $0.983 * *$ & 1 & & & & & & & & & \\
\hline $\mathrm{N}_{2} \mathrm{O}$ & $0.573 * *$ & $0.413 *$ & 1 & & & & & & & & \\
\hline $\mathrm{CO}$ & $0.475^{*}$ & $0.392 *$ & $0.605^{* *}$ & 1 & & & & & & & \\
\hline NMVOC & $0.472^{*}$ & $0.389 *$ & $0.606^{* *}$ & $0.989 * *$ & 1 & & & & & & \\
\hline NOx & $0.466^{*}$ & $0.382 *$ & $0.604 * *$ & $0.997 * *$ & $0.999 * *$ & 1 & & & & & \\
\hline SOx & $0.487 * *$ & $0.405^{*}$ & $0.611 * *$ & $0.987 * *$ & $0.986^{* *}$ & $0.988^{* *}$ & 1 & & & & \\
\hline $\mathrm{PM}_{10}$ & $0.522 * *$ & 0.457 * & $0.550 * *$ & $0.972 * *$ & $0.970 * *$ & $0.969 * *$ & $0.986 * *$ & 1 & & & \\
\hline $\mathrm{PM}_{2.5}$ & $0.520 * *$ & $0.455^{*}$ & $0.551 * *$ & $0.972 * *$ & $0.970 * *$ & $0.970 * *$ & $0.986 * *$ & $0.999 * *$ & 1 & & \\
\hline $\mathrm{BC}$ & $0.499 * *$ & $0.424 *$ & $0.585^{* *}$ & $0.995^{* *}$ & $0.994 * *$ & $0.993 * *$ & $0.993 * *$ & $0.991 * *$ & $0.991 * *$ & 1 & \\
\hline TSP & $0.518 * *$ & $0.452 *$ & $0.547 * *$ & $0.971 * *$ & $0.969 * *$ & $0.969 * *$ & $0.986^{* *}$ & $0.999 * *$ & $0.999 * *$ & $0.990 * *$ & 1 \\
\hline
\end{tabular}

coefficients are positive, indicating simultaneous change. This is probably due to the type of engines and fuel used.

*Correlation significant at the 0.05 level.

**Correlation significant at the 0.01 level.

In the next phase, in order to find groups of pollutants with similar behavior, the PCA technique was applied. According to the PCA results for road transport, the first two principal components extracted explain $93.1 \%$ of the variance. Specifically, the first component (PC1) explains $67.8 \%$ of the total variance, and consists of $\mathrm{CH}_{4}, \mathrm{~N}_{2} \mathrm{O}, \mathrm{CO}$, NMVOC, NOx, $\mathrm{PM}_{10}, \mathrm{PM}_{2.5}$, BC, TSP. These are pollutants that mainly originate from incomplete combustion. The rest of pollutants are grouped in the second component (PC2) which explains $25.3 \%$ of the variance (Table 5).

Tables S12-S15 present the PCA results for each branch of the road sector, separately. Specifically, for passenger cars (Table S12) and light-duty vehicles (Table S13), the first component extracted consists of $\mathrm{CH}_{4}, \mathrm{CO}, \mathrm{NH}_{3}$, NMVOC, NOx, SOx, $\mathrm{PM}_{10}, \mathrm{PM}_{2.5}, \mathrm{BC}$ and TSP, while the second consists of $\mathrm{CO}_{2}$ and $\mathrm{N}_{2} \mathrm{O}$. For heavy-duty vehicles (Table S14), the results are almost similar to the ones from the total road sector, with the main difference being the inclusion of $\mathrm{CH}_{4}$ in $\mathrm{PC} 2$. On the other hand, mopeds and motorcycles (Table S15) follow a different pattern, with the first component consisting of $\mathrm{CO}_{2}, \mathrm{CH}_{4}, \mathrm{~N}_{2} \mathrm{O}, \mathrm{NH}_{3}$, NMVOC, NOx, SOx, $\mathrm{PM}_{10}, \mathrm{PM}_{2.5}$ and TSP (and explaining $65.8 \%$ of the total variance) and the second consisting of $\mathrm{CO}$ and $\mathrm{BC}$ (and explaining $30.6 \%$ of the total variance). These differences probably reflect the different type of engines and fuel used.

For the railway (Table S16), the two components extracted explain $99.8 \%$ of the total variance. The first (explaining $91.5 \%$ of the variance) comprises all pollutants except for SOx, while the second, consisting of SOx, explains $8.3 \%$ of the total variance.

For navigation, the two components extracted explain $94 \%$ of the variation. The first component, consisting of $\mathrm{N}_{2} \mathrm{O}, \mathrm{CO}, \mathrm{NMVOC}, \mathrm{NOx}, \mathrm{SOx}, \mathrm{PM}_{10}, \mathrm{PM}_{2.5}, \mathrm{BC}$ and TSP, 
Table 5 PCA component matrix for the emissions from the road transport sector. Loadings lower than 0.4 are not shown

\begin{tabular}{lrr}
\hline & PC1 & PC2 \\
\hline $\mathrm{CO}_{2}$ & & $\mathbf{0 . 9 6 8}$ \\
$\mathrm{CH}_{4}$ & $\mathbf{0 . 8 9 8}$ & \\
$\mathrm{N}_{2} \mathrm{O}$ & $\mathbf{0 . 6 9 0}$ & 0.551 \\
$\mathrm{CO}$ & $\mathbf{0 . 9 0 2}$ & -0.400 \\
$\mathrm{NH}_{3}$ & -0.435 & $\mathbf{0 . 7 7 0}$ \\
$\mathrm{NMVOC}$ & $\mathbf{0 . 6 8 4}$ & -0.476 \\
$\mathrm{NOx}$ & $\mathbf{0 . 9 7 5}$ & \\
$\mathrm{SOx}$ & 0.659 & $\mathbf{0 . 7 0 3}$ \\
$\mathrm{PM}_{10}$ & $\mathbf{0 . 9 7 2}$ & \\
$\mathrm{PM}_{2.5}$ & $\mathbf{0 . 9 8 8}$ & \\
$\mathrm{BC}$ & $\mathbf{0 . 9 7 1}$ & \\
$\mathrm{TSP}$ & $\mathbf{0 . 9 2 5}$ & \\
Total & $67.8 \%$ & $25.3 \%$ \\
Variance & & \\
Explained & & \\
\hline
\end{tabular}

explains $80.2 \%$ of the variation, while the second, consisting of $\mathrm{CH}_{4}$ and $\mathrm{CO}_{2}$, explains $13.8 \%$ (Table 6). The grouping probably reflects the different type of engines.

Finally, for aviation (Table S17), the two components extracted sum up to $91.1 \%$ of the variance. Specifically, the first component (non-greenhouse term) explains $69.6 \%$, while the second explains $21.5 \%$ and comprises the GHGs (greenhouse term). This grouping makes sense, as the major environmental impact from the life cycle of kerosene is the acidification effect, followed by the greenhouse effect. The summer smog and eutrophication effect have much less severe impact (Koroneos et al. 2005).

In order to further investigate and identify groupings among pollutants, the plots of PCA components were studied (Fig. 7a-d). Specifically, for the road sector (Fig. 7a), six main groups of pollutants were found. The first group

Table 6 PCA component matrix for the emissions from the navigation sector. Loadings lower than 0.4 are not shown

\begin{tabular}{lrl}
\hline & PC1 & PC2 \\
\hline $\mathrm{CO}_{2}$ & 0.613 & $\mathbf{0 . 7 8 8}$ \\
$\mathrm{CH}_{4}$ & 0.553 & $\mathbf{0 . 8 1 7}$ \\
$\mathrm{N}_{2} \mathrm{O}$ & $\mathbf{0 . 6 5 8}$ & \\
$\mathrm{CO}$ & $\mathbf{0 . 9 8 1}$ & \\
$\mathrm{NMVOC}$ & $\mathbf{0 . 9 8 0}$ & \\
$\mathrm{NOx}$ & $\mathbf{0 . 9 7 9}$ & \\
$\mathrm{SOx}$ & $\mathbf{0 . 9 8 5}$ & \\
$\mathrm{PM}_{10}$ & $\mathbf{0 . 9 8 3}$ & \\
$\mathrm{PM}_{2.5}$ & $\mathbf{0 . 9 8 4}$ & \\
$\mathrm{BC}$ & $\mathbf{0 . 9 8 9}$ & \\
TSP & $\mathbf{0 . 9 8 2}$ & \\
Total & $80.2 \%$ & $13.8 \%$ \\
Variance & & \\
Explained & & \\
\hline
\end{tabular}

consists of $\mathrm{CO}_{2}$, (complete combustion term) the second of $\mathrm{NH}_{3}$, the third of $\mathrm{N}_{2} \mathrm{O}$, the fourth of $\mathrm{CH}_{4}$, TSP, $\mathrm{PM}_{10}, \mathrm{PM}_{2.5}$, $\mathrm{NO}_{\mathrm{x}}, \mathrm{BC}$ (particulates term), the fifth of $\mathrm{CO}$ and NMHCs (incomplete combustion term) and the sixth of SOx. Regarding the four branches of the road sector separately (Figures S1-4), the various differences observed (especially for mopeds and motorcycles) probably reflect the different driving conditions, the types of fuel used and the type of engine.

For the railway sector (Fig. 7b), 2 main groups were isolated; the first consists of SOx, while the second is comprised of the rest of pollutants. For the navigation sector (Fig. 7c), 3 main groups of pollutants were found: one consisting of SOx, NOx, CO, NMVOC and particulates that can be characterized as the photochemical term, a second consisting of $\mathrm{N}_{2} \mathrm{O}$ and the last consisting of $\mathrm{CH}_{4}$ and $\mathrm{CO}_{2}$. Finally, for aviation (Fig. 7d), four groups were identified. The first group consists of $\mathrm{CO}_{2}, \mathrm{~N}_{2} \mathrm{O}$ and $\mathrm{CH}_{4}$ (greenhouse gases term), the second of $\mathrm{CO}$ (incomplete combustion term), the third of SOx, NOx, $\mathrm{PM}_{10}, \mathrm{PM}_{2.5}$, BC (fuel used term) and the last of NMVOCs (photochemical term). d PCA components plot for the emissions from the aviation sector.

\section{Conclusions and recommendations for transport-related emission mitigation}

This work studies the trends of emissions from the four transport sectors in Greece, namely road transport, aviation, navigation and railway, between 1990-2017. Our key findings and conclusions are listed below:

- Although the total GHG emissions in Greece were reduced by $7.5 \%$ during the period studied, our analysis shows that the transport sector GHG and other pollutants emissions increased.

- This increase was temporarily restrained during the fiscal recession of 2008 that decelerated almost all types of economic activity in the country. During the years that followed 2008, a reduction in the use of private cars was observed, while the reduced economic activity likewise resulted in reduced use of heavy and light-duty vehicles.

- The economic recovery that followed was accompanied by an increase of emissions. This increase was enhanced by the rapid development of the touristic sector, which in 2019 summed up to almost 33 million arrivals of foreign tourists in the country; a number almost $40 \%$ higher than 2013.

On the whole, all sectors of transport (with the exception of railway) increased their emissions during the period studied. This growth of the transport sector and its significant share in atmospheric pollution and the total GHG emissions (37\%), apart from degrading the environmental 
a

ำ

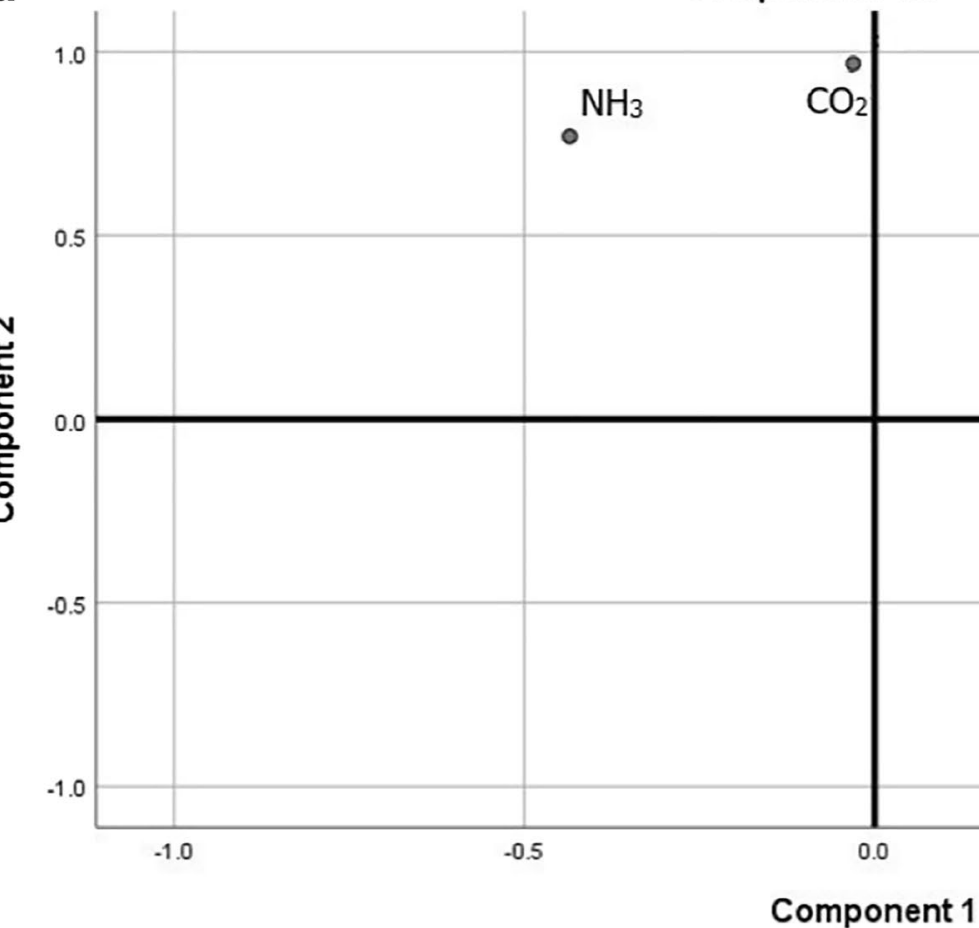

$\mathrm{N}_{2} \mathrm{O}$

$\mathrm{CH}_{4} \circ \circ^{\mathrm{TSP}}$

$\mathrm{NO}_{\mathrm{x}} \mathrm{PM}_{10}$

$\mathrm{BC}^{\circ} \mathrm{PM}_{2.5}$

CO

NMVOC

-

$\mathrm{SO} x$

b

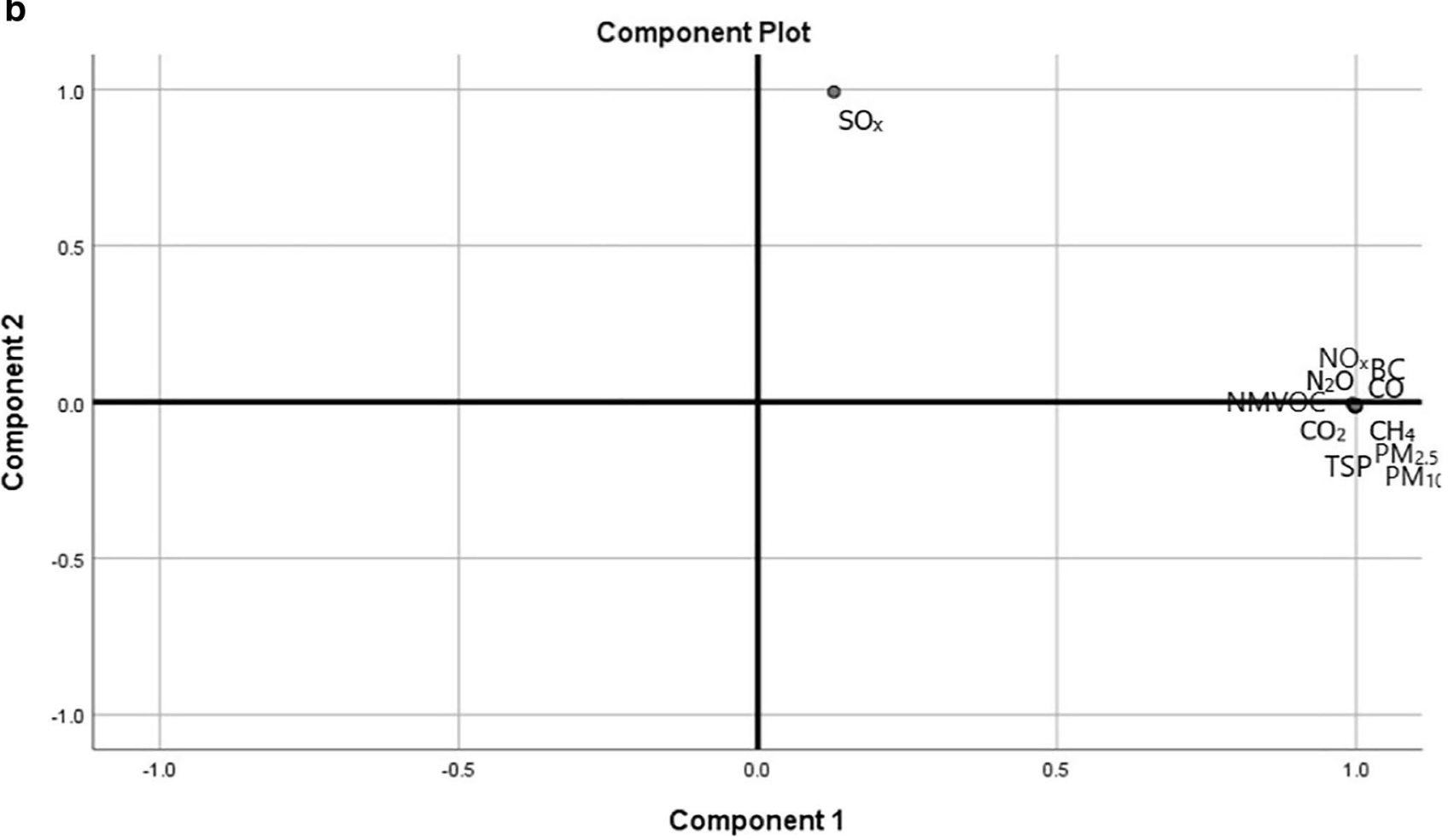

Fig. 7 a PCA components plot for the emissions from the road transport. b PCA components plot for the emissions from the railway sector.c PCA components plot for the emissions from the navigation sector 
C

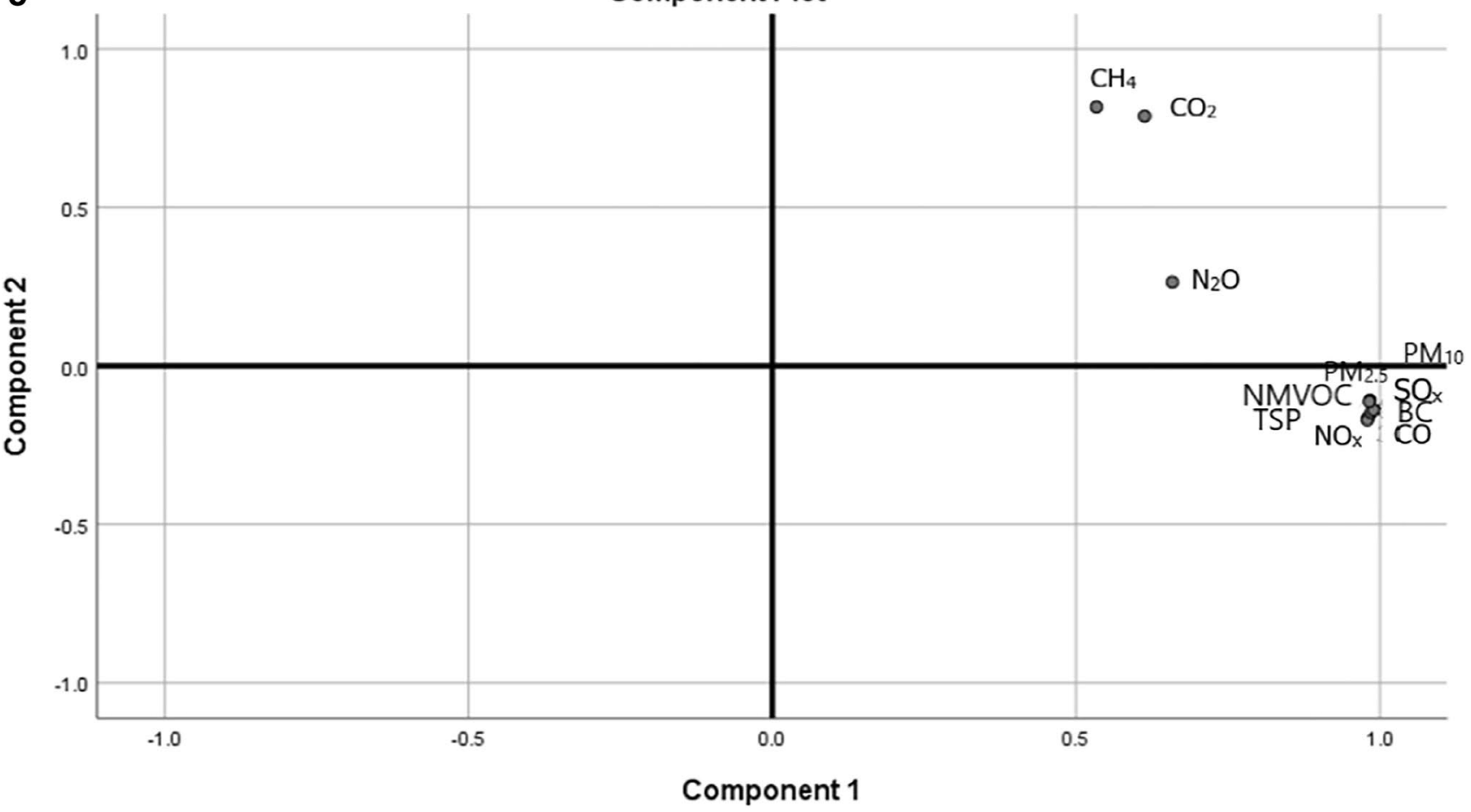

d

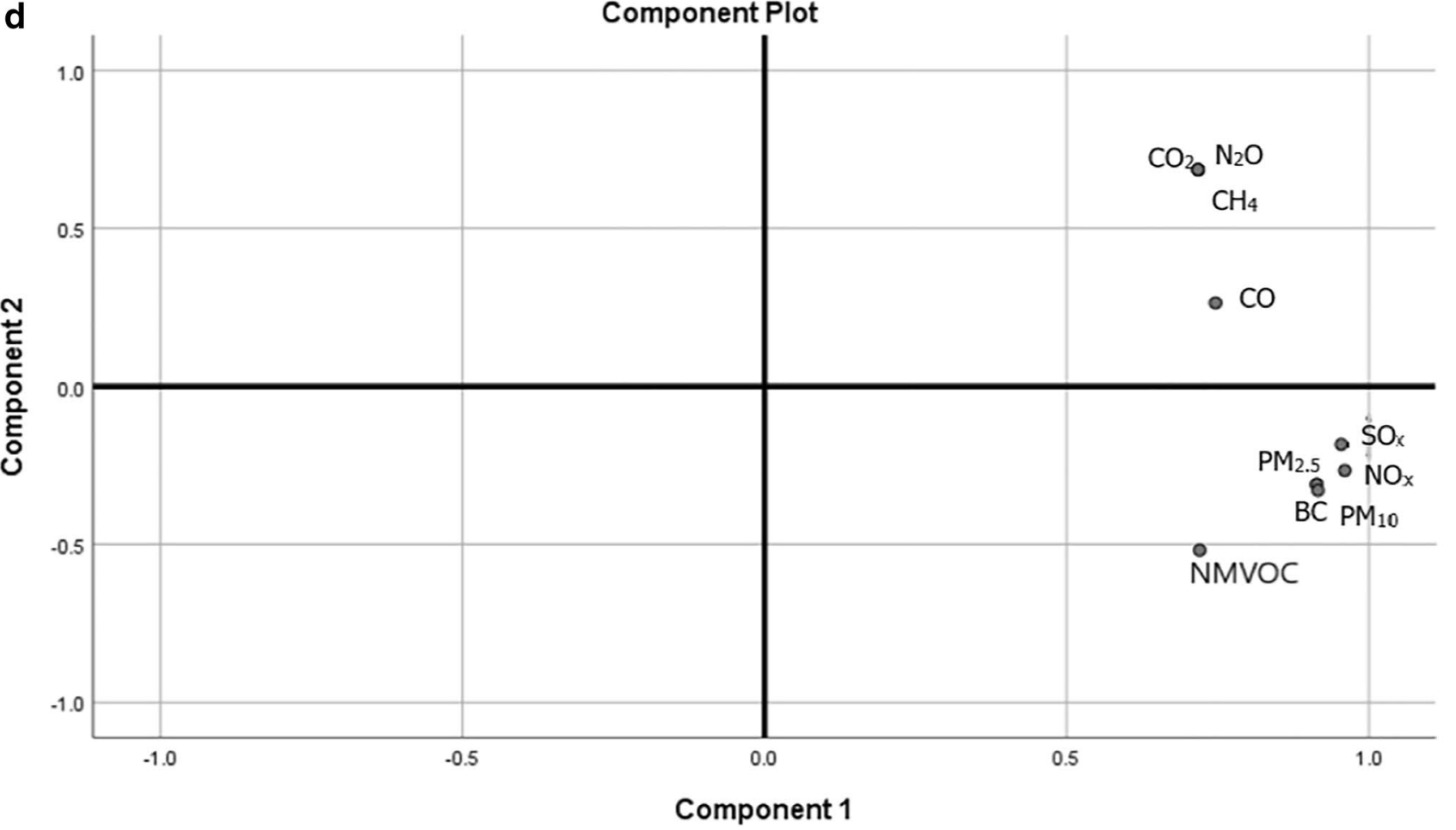

Fig. 7 (continued)

quality, contradicts the relevant EU direction, according to which the GHG emissions need to be reduced by $40 \%$ up to 2030 , starting as of January $1^{\text {st }}, 2020$. In order to comply with the 2019/631 Regulation for $\mathrm{CO}_{2}$ emission standards for passenger and light commercial vehicles (www.eur-lex. europa.eu/eli/reg/2019/631), policies aiming at the reduction of emissions must be applied. Generally speaking, opting for public transport or driving more efficiently can 
have a significant impact on GHGs from the road sector. Additionally, improvements in engine technology result in a significant and continuous increase in fuel efficiency for car engines. Along these lines, specific recommendations are listed below:

- Given that Greece holds certain unique characteristics related to its car fleet, as well as the transport sector in general, individual policies for both of them merit study. Specifically, the country has one of the oldest vehicle fleets in the European Union in all categoriesincluding LDV and HDV - with the average vehicle age reaching 13.5 years in 2015, according to data from the European Automobile Manufacturers Association (ACEA). This is mainly attributed to the economic crisis, as many owners of old vehicles were unable to replace them, but also to the lack of relevant incentives for the purchase of new cars and, conversely, multiple incentives for the use of old ones. Given their major contribution to the total road transport emissions, it is essential to replace the old fleet of LDV and HDV with a newer one, that utilizes low-emission technology and alternative fuels. During the transition from the old car fleet to the new, vehicle inspections for old cars should be strict and unbiased.

- Additionally, policies should aim to encourage the replacement of passenger cars with low-emission cars, such as hybrid cars using the Euro-6c technology. Incentives that make electric vehicles more affordable could play a key role in lowering the GHG emissions from the road transport sector. The adoption of biofuels and liquid gas as alternative fuels should also be considered.

- Furthermore, in the two biggest cities of Greece (i.e. Athens and Thessaloniki) where half of the total population resides, there is a significant lack of parking space, resulting in a notable increase in driving time. As opposed to most EU counties, private parking in Greece is much more expensive during the first hour, a fact which incentivizes drivers to spend more time looking for an empty free parking spot. Creating more free parking space for the public would also help improving the situation.

- Moreover, the use of public transport should be encouraged by means of frequent, eco-friendly and cheap transportations. Taxation measures that discourage private vehicles' use and encourage other modes of public transport can also be effective.

- Finally, given the high potential of the tourist industry in the country, the sectors of aviation and navigation need to adapt to the new challenges, by means of promoting more contemporary and energy-efficient technologies; an attempt frequently referred to as electromobilization.
Supplementary Information The online version contains supplementary material available at https://doi.org/10.1007/s11356-021-18062-5.

Acknowledgements The authors would like to thank the Greek Ministry of Environment and the United Nations Framework Convention on Climate Change (UNFCCC) (http://unfccc.int) for the data used in this study.

Author contribution AP and PK presented the idea for the article and performed the literature search. They drafted the structure and performed data analyses together with IP. GF critically reviewed the work, and revised the manuscript. All authors technically checked and finalized the manuscript.

Data availability The datasets used and/or analyzed during the current study are available from the corresponding author on reasonable request.

\section{Declarations}

Ethics approval and consent to participate Not applicable.

Consent for publication Not applicable.

Competing interests The authors declare no competing interests.

\section{References}

Adesina J.A., S.J. Piketh, M. Qhekwana, R. Burger, B. Language, G. Mkhatshwa, 2020. Contrasting indoor and ambient particulate matter concentrations and thermal comfort in coal and non-coal burning households at South Africa Highveld. Science of the Total Environment, 699, 134403.

Andreae MO, Merlet P (2001) Emission of trace gases and aerosols from biomass burning. Global Biogeochem Cy 15:955-966

Bebkiewicz K, Chłopek Z, Lasocki J, Szczepanski K, ZimakowskaLaskowska M (2020) Analysis of Emission of Greenhouse Gases from Road Transport in Poland between 1990 and 2017. Atmosphere 11:387. https://doi.org/10.3390/atmos11040387

Behera SN, Sharma M, Aneja VP, Balasubramanian R (2013) Ammonia in the atmosphere: a review on emission sources, atmospheric chemistry and deposition on terrestrial bodies. Environ Sci Pollut Res Int 20(11):8092-8131. https://doi.org/10.1007/s11356-0132051-9 (PMID: 23982822)

Bignal KL, Ashmore MR, Headly AD, Stewart K, Weigert K (2007) Ecological impacts of air pollution. J Allergy Clin Immunol 114(5):1116-1123

Bishop GA, Stedman DH (2008) A decade of on-road emissions measurements. Environ Sci Technol 42:1651-1656

Carslaw D, Murrels T, Andersson J, Keenan M (2016) Have vehicle emissions of primary NO2 peaked? Faraday Discuss 18(189):439-454

Cattani G, Di Menno A, di Bucchianico D, Dina M, Inglessis C, Notaro G, Settimo GV, Marconi A (2010) Evaluation of the temporal variation of air quality in Rome, Italy, from 1999 to 2008. Ann Ist Super Sanita 46(3):242-253. https://doi.org/10.4415/ANN_10_ 03_04 (PMID: 20847456)

Crippa M., G. Oreggioni, D. Guizzardi, M. Muntean, E. Schaaf, E. Lo Vullo, E. Solazzo, F. Monforti-Ferrario, J.G.J.Olivier and E. Vignati, 2019. Fossil CO2 and GHG emissions of all world countries - 2019 Report, EUR 29849 EN, Publications Office of the 
European Union, Luxembourg, 2019, ISBN 978-92-76-11100-9, doi:https://doi.org/10.2760/687800, JRC117610.

de Miranda Pinto JT, Mistage O, Bilotta P, Helmers E (2018) Roadrail intermodal freight transport as a strategy for climate change mitigation. Environmental Development 25:100-110

Linares C, Díaz J, Negev M, Sanchez Martinez G, Debono R, Paz S (2020) Impacts of climate change on the public health of the Mediterranean Basin population - Current situation, projections, preparedness and adaptation. Environ Res 182:109107

Giechaskiel B (2020) Gaseous and Particulate Emissions of a Euro 4 Motorcycle and Effect of Driving Style and Open or Closed Sampling Configuration. Sustainability 12:9122

Heinold A, Meisel F (2018) Emission rates of intermodal rail/road and road-only transportation in Europe: A comprehensive simulation study. Transp Res Part d: Transp Environ 65:421-437

Hoek G, Brunekreef B, Fischer P, van Wijnen J (2001) The association between air pollution and heart failure, arrhythmia, embolism, thrombosis and other cardiovascular causes of death in a time series study. Epidemiology 12:355-357

https://ec.europa.eu/clima/eu-action/transport-emissions/reducingemissions-aviation_en

https://ec.europa.eu/clima/eu-action/transport-emissions/reducingemissions-shipping-sector_en

https://ec.europa.eu/clima/eu-action/transport-emissions/road-trans port-reducing-co2-emissions-vehicles/co2-emission-perfo rmance-standards-cars-and-vans_en

Huang J, Yu H, Guan X, Wang G, Guo R (2016) Accelerated dryland expansion under climate change. Nat Clim Chang 6:166-172

Huang R, Hubacek K, Feng K, Li X, Zhang C (2018) Re-Examining Embodied $\mathrm{SO}_{2}$ and $\mathrm{CO}_{2}$ Emissions in China. Sustainability 10:1505

Iarocci G, Cocchiara RA, Sestili C, Del Cimmuto A, La Torre G (2019) Variation of atmospheric emissions within the road transport sector in Italy between 1990 and 2016. Sci Total Environ 692:1276-1281

IPCC (2013) Climate change 2013: the physical science basis. Contribution of working group I to the fifth assessment report of the intergovernmental panel on climate change [Stocker, TF, D Qin, G-K Plattner, M Tignor, SK Allen, J Boschung, A Nauels, Y Xia, V Bex and PM Midgley (eds)]. Cambridge University Press, Cambridge, United Kingdom and New York, NY, pp 1535. https://doi.org/10.1017/CBO9781107415324

IPCC 2006, 2006 IPCC Guidelines for National Greenhouse Gas Inventories, Prepared by the National Greenhouse Gas Inventories Programme, Eggleston H.S., Buendia L., Miwa K., Ngara T. and Tanabe K. (eds). Published: IGES, Japan.

Kendall M, Gibbons JD (1990) Rank correlation methods. Oxford University Press, New York

Kim HJ, Fay MP, Feuer EJ, Midthune DN (2000) Permutation tests for joinpoint regression with applications to cancer rates. Stat Med 19(3):335-351

Kjellström E, Nikulin G, Hansson U, Strandberg G, Ullerstig A (2011) 21 st century changes in the European climate: Uncertainties derived from an ensemble of regional climate model simulations. Tellus, Series a: Dynamic Meteorology and Oceanography 63(1):24-40

Koroneos C, Nanaki E (2007) Environmental assessment of the Greek transport sector. Energy Policy 35(11):5422-5432

Koroneos C, Dompros A, Roumbas G, Moussiopoulos N (2005) Life Cycle Assessment of Kerosene Used in Aviation (8 pp). Int J Life Cycle Assessment 10:417-424. https://doi.org/10.1065/lca2004. 12.191

Lachatre M, Fortems-Cheiney A, Foret G, Siour G, Dufour G, Clarisse L, Clerbaux C, Coheur P-F, Van Damme M, Beekmann M (2019) The unintended consequence of $\mathrm{SO}_{2}$ and $\mathrm{NO}_{2}$ regulations over China: increase of ammonia levels and impact on PM2.5 concentrations. Atmos Chem Phys 19:6701-6716. https://doi.org/ 10.5194/acp-19-6701

Landrigan PJ, Fuller R, Acosta NJR, Adeyi O, Arnold R, Basu N, Bibi Baldé A, Bertollini R, Bose-O'Reilly S, Ivey Boufford J, Breysse PN, Chiles T, Mahidol C, Coll-Seck AM, Cropper ML, Fobil J, Fuster V, Greenstone M, Haines A, Hanrahan D, Hunter D, Khare M, Krupnick A, Lanphear B, Lohani B, Martin K, Mathiasen KV, McTeer MA, Murray CJL, Ndahimananjara JD, Perera F, Potočnik J, Preker AS, Ramesh J, Rockström J, Salinas C, Samson LD, Sandilya K, Sly PD, Smith KR, Steiner A, Stewart RB, Suk WA, van Schayck OCP, Yadama GN, Yumkella K, Zhong M (2017) The Lancet Commission on pollution and health. The Lancet 391:10119

Lehtipalo K., C. Yan, , L. Dada, , F. Bianchi, , M.Xiao, , R. Wagner, , D. R. Worsnop, 2018. Multicomponent new particle formation from sulfuric acid, ammonia, and biogenic vapors. Science Advances. 1-9https://doi.org/10.1126/sciadv.aau5363

Lo PL, Martini G, Porta F, Scotti D (2020) The determinants of $\mathrm{CO}_{2}$ emissions of air transport passenger traffic: An analysis of Lombardy (Italy). Transp Policy 91:108-119

Matthes S, Grewe V, Sausen R, Roelofs G-J (2007) Global impact of road traffic emissions on tropospheric ozone. Atmos Chem Phys 7:1707-1718

Matthias V., J. Bieser, T. Mocanu, T. Pregger, M. Quante, M. Ramacher, S. Seum and C. Winkler, 2020. Modelling road transport emissions in Germany - Current day situation and scenarios for 2040. Transportation Research Part D: Transport and Environment, Volume $\mathbf{8 7}, 102536$.

Murena F, Mocerino L, Quaranta F, Toscano D (2018) Impact on air quality of cruise ship emissions in Naples, Italy. Atmos Environ 187:70-83

Ntziachristos L., Gkatzoflias D., Kouridis C., Samaras Z., 2009. COPERT: A European Road Transport Emission Inventory Model. In: Athanasiadis I.N., Rizzoli A.E., Mitkas P.A., Gómez J.M. (eds) Information Technologies in Environmental Engineering. Environmental Science and Engineering. Springer, Berlin, Heidelberg. https://doi.org/10.1007/978-3-540-88351-7_37

Nuñez-Alonso D., L. V. Perez-Arribas, S. Manzoor and J. O. C'aceres, 2019. Statistical tools for air pollution assessment: multivariate and spatial analysis studies in the Madrid Region. J Anal Methods Chem. 1-9

Olivier J.G., K.M. Schure and J.A.H.W. Peters, 2017. Trends in Global $\mathrm{CO}_{2}$ and total greenhouse Gas Emissions. Summary of the 2017 Report. PBI. Netherlands, Environmental Assessment Agency. The Hague.

Patz JA, Cambell-Lendrum D, Holloway T, Foley JA (2005) Impact of regional climate change on human health. Nature 438(7006):310

Pope CA, Dockery DW (2006) Health effects of fine particulate air pollution: lines that connect. Air and Waste Management Association 56:709-742

Reisen F, Powell JC, Dennekamp M, Johnston FH, Wheeler AJ (2019) Is remaining indoors an effective way of reducing exposure to fine particulate matter during biomass burning events? J Air Waste Manag Assoc 69(5):611-622

Ritchie H. and M. Roser, 2018. $\mathrm{CO}_{2}$ and other greenhouse gas emissions. Published online at our worldindata.org. www.ourworldin data.org/co2-and-other-greenhouse-gas-emissions.

Roinioti A, Koroneos C (2017) The decomposition of CO2 emissions from energy use in Greece before and during the economic crisis and their decoupling from economic growth. Renew Sustain Energy Rev 76:448-459

Sadorsky P (2020) Energy Related CO2 Emissions before and after the Financial Crisis. Sustainability 12:3867

Salvati L (2014) Toward a "Sustainable" land degradation? Vulnerability degree and component balance in a rapidly changing environment. Environ Dev Sustain 16(1):239-254 
Sirois A., 1998. A Brief and Biased Overview of Time Series Analysis or How to Find that Evasive Trend. In WMO report No. 133: WMO/EMEP workshop on Advanced Statistical methods and their Application to Air Quality Data sets (Helsinki, 14-18 September 1998).

Sobrino N, Monzon A (2018) Towards Low-Carbon Interurban Road Strategies: Identifying Hot Spots Road Corridors in Spain. Sustainability 10(11):3963

Stott PA, Stone DA, Allen MR (2004) Human contribution to the European heatwave of 2003. Nature 432(7017):610

Turnbull JC, Miller JB, Lehman SJ, Tans PP, Sparks RJ, Southon J (2006) Comparison of (CO2)-C-14, CO, and SF6 as tracers for recently added fossil fuel $\mathrm{CO} 2$ in the atmosphere and implications for biological CO2 exchange. Geophys Res Lett 33(L01817):2006. https://doi.org/10.1029/2005GL024213

Uherek E, Halenka T, Borken-Kleefeld J, Balkanski Y, Berntsen T, Borrego C, Gauss M, Hoor P, Juda-Rezler K, Lelieveld J (2010) Transport impacts on atmosphere and climate: Land transport. Atmos Environ 11:4772-4816
Valavanidis A., T. Vlachogianni, S. Loridas and C. Fiotakis, 2015. Atmospheric Pollution in Urban Areas of Greece and Economic Crisis. Trends in air quality and atmospheric pollution data. Research and adverse health effects. (Editions of Chemical Department of University of Athens, Greece.)

Vasic AM, Weilenmann M (2006) Comparison of real-world emissions from two-wheelers and passenger cars. Environ Sci Technol 40(1):149-154. https://doi.org/10.1021/es0481023 (PMID: 16433345)

Viatte C, Wang T, Van Damme M, Dammers E, Meleux F, Clarisse L, Shephard MW, Whitburn S, Coheur PF, Cady-Pereira KE, Clerbaux C (2020) Atmospheric ammonia variability and link with particulate matter formation: A case study over the Paris area. Atmos Chem Phys 20(577-596):2020. https://doi.org/10.5194/ acp-20-577-2020

Publisher's note Springer Nature remains neutral with regard to jurisdictional claims in published maps and institutional affiliations. 